\title{
Analisis Tingkat Sirkulasi Alamiah pada Liquid Metal Fast Breeder Reactor dengan Pendingin Na, NaK, Pb dan $\mathrm{Pb}-\mathrm{Bi}$
}

\author{
Refi Juita*, Dian Fitriyani \\ Laboratorium Fisika Nuklir, Jurusan Fisika \\ Fakultas Matematika dan Ilmu Pengetahuan Alam Universitas Andalas \\ Kampus UNAND Limau Manih, Padang 25163, Indonesia \\ *juitarevika@gmail.com
}

\begin{abstract}
ABSTRAK
Telah dilakukan analisis tingkat sirkulasi alamiah pada LMFBR (Liquid Metal Fast Breeder Reactor) dengan bahan pendingin $\mathrm{Na}, \mathrm{NaK}, \mathrm{Pb}$ dan $\mathrm{Pb}-\mathrm{Bi}$. Perhitungan neutronik dan termalhidrolik pada penelitian ini menggunakan program DTRIDI berbasis delphi7 yang merupakan program simulasi untuk desain teras tiga dimensi (xyz). Teras LMFBR dirancang dengan bahan bakar UN-PuN dan beroperasi pada daya $150 \mathrm{MWth}$. Simulasi diawali dengan perhitungan neutronik yang memberikan hasil faktor multiplikasi neutron yang digunakan untuk perhitungan termalhidrolik sehingga diperoleh distribusi temperatur dan penurunan tekanan. Analisis tingkat sirkukasi alamiah dilakukan dengan pendekatan kuasistatik, dimana laju aliran massa pendingin total diturunkan secara bertahap untuk mensimulasikan hilangnya daya pompa pada keadaan kecelakaan ULOF (Unprotected Lost Of Flow). Tingkat sirkulasi alamiah diperoleh dari grafik perpotongan antara pressure drop dan driving head sebagai fungsi dari laju alir pendingin total. Sirkulasi alamiah tercapai lebih cepat pada penggunaan bahan pendingin $\mathrm{Pb}$ dan $\mathrm{Pb}-$ Bi yaitu sekitar 27,5\% dari laju aliran pendingin mula-mula, sedangkan untuk penggunaan pendingin $\mathrm{Na}$ dan $\mathrm{NaK}$ hampir tidak terjadi sirkulasi alamiah yang berarti reaktor dalam keadaan bahaya jika terjadi kecelakaan ULOF.

Kata kunci: sirkulasi alamiah, LMFBR, ULOF, $\mathrm{Na}, \mathrm{NaK}, \mathrm{Pb}, \mathrm{Pb}-\mathrm{Bi}$
\end{abstract}

\section{ABSTRACT}

Natural circulation level analysis has been carried out on LMFBR (Liquid Metal Fast Breeder Reactor) with coolant $\mathrm{Na}, \mathrm{NaK}, \mathrm{Pb}$ and $\mathrm{Pb}$-Bi. The neutronic and thermal hydraulics calculations in this study used the delphi7-based DTRIDI program which is a simulation program for three-dimensional core design (xyz). The LMFBR core is designed with UN-PuN fuel and operates at $150 \mathrm{MWth}$. The simulation begins with a neutron calculation which results in a neutron multiplication factor used for thermal hydraulic calculations so that the temperature distribution and pressure drop are obtained. Natural circulation level analysis is carried out by the quasi-static approach, where the total coolant mass flow rate is gradually reduced to simulate the loss of pump power at the ULOF (Unprotected Lost Of Flow) accident. The natural circulation level is obtained from line interception between the pressure drop and driving head as a function of total coolant mass flow rate. Natural circulation is achieved more quickly in the use of $\mathrm{Pb}$ and $\mathrm{Pb}$-Bi coolant, which is about 27.5\% of the initial coolant flow rate, whereas for the use of coolant $\mathrm{Na}$ and NaK there is almost no natural circulation which means the reactor is in danger of ULOF accident due to loss of pump power.

Key word: natural circulation, $L M F B R, U L O F, N a, N a K, P b, P b-B i$

\section{PENDAHULUAN}

Reaktor nuklir merupakan tempat terjadinya reaksi fisi berantai terkendali. Generasi Pembangkit Listrik Tenaga Nuklir (PLTN) mengalami perkembangan yang cukup pesat, dari reaktor generasi I hingga generasi IV. Reaktror generasi IV terdiri dari jenis-jenis reaktor daya yang lebih inovatif dari reaktor generasi sebelumnya. Keunggulan dari reaktor generasi IV adalah aspek ekonomi yang tinggi, menghasilkan limbah dengan kuantitas yang sangat rendah, tingkat keselamatan lanjut, dan tahan terhadap aturan NPT (Nuclear Non-Proliferation Treaty). NPT memuat aturan dimana nuklir digunakan untuk kepentingan damai dan tidak memungkinkan untuk dikembangkan menjadi senjata nuklir.

Aspek keamanan adalah satu aspek pada perancangan reaktor nuklir yang merupakan gabungan dari analisis neutronik dan analisis termalhidrolik. Reaktor diharapkan mampu bertahan secara mandiri tanpa mengalami pemadaman otomatis atau bantuan dari operator pada saat terjadi kecelakaan (kondisi abnormal) yang disebut dengan keselamatan inheren (inherent safety). Salah satu jenis kecelakaan yang mungkin terjadi adalah kecelakaan jenis ULOF (Unprotected Loss Of Flow) yang merupakan kecelakaan dimana aliran bahan pendingin akan 
menurun akibat hilangnya daya pompa tanpa proteksi. Hal ini menyebabkan temperatur pendingin meningkat karena ketidakseimbangan antara daya dan aliran pendingin, kondisi ini akan berbahaya jika batasan-batasan termal pada bahan struktur terlampaui. Tetapi kenaikan temperatur ini menyebabkan terjadinya reaktivitas umpan balik negatif yang kemudian menekan daya untuk turun dan akhirnya menyesuaikan dengan kemampuan sirkulasi alamiah.

Sirkulasi alamiah merupakan kemampuan material pendingin untuk bersirkulasi terus menerus akibat adanya perbedaan temperatur panas dan dingin pada pipa pendingin. Aliran fluida timbul karena gaya apung dari fluida pendingin tersebut. Sirkulasi alamiah sangat penting untuk dianalisis pada aliran pendingin sehingga reaktor dapat berada pada kondisi yang mendukung tercapainya keselamatan inheren pada reaktor ketika terjadi kecelakaan akibat hilangnya daya pompa utama pada reaktor nuklir.

Studi fenomena sirkulasi alamiah pada pendingin $\mathrm{Pb}-\mathrm{Bi}$ juga telah dilakukan oleh Novitrian dan Sofue (2004) dimana aliran sirkulasi alamiah berhasil dicapai pada heater pin bundle. Penelitian ini memberikan hasil eksperimen kecepatan aliran pendingin $\mathrm{Pb}-\mathrm{Bi}$ pada kondisi sirkulasi alamiah yang sedikit lebih tinggi dari perhitungan analitik.

Oktamuliani (2011) telah melakukan analisis pengaruh ukuran teras terhadap tingkat sirkulasi alamiah bahan pendingin $\mathrm{Pb}-\mathrm{Bi}$ pada reaktor cepat, dan disimpulkan bahwa geometri kubus dengan ukuran teras $\mathrm{x}=\mathrm{y}=\mathrm{z}=50 \mathrm{~cm}$ memenuhi aspek neutronik dan mencapai tingkat sirkulasi alamiah yang lebih baik dibandingkan dengan ukuran yang lebih besar.

Pada penelitian ini dilakukan analisis tingkat sirkulasi alamiah terhadap penggunaan bahan pendingin $\mathrm{Na}, \mathrm{NaK}, \mathrm{Pb}$, dan $\mathrm{Pb}$-Bi pada LMFBR. Melalui penelitian ini diharapkan diperoleh bahan pendingin yang memiliki respon yang lebih baik berdasarkan perameterparameter neutronik, termalhidrolik dan tingkat sirkulasi alamiah.

\section{METODE}

Penelitian untuk menganalisis tingkat sirkulasi alamiah terhadap beberapa bahan pendingin yaitu $\mathrm{Na}, \mathrm{NaK}, \mathrm{Pb}$ dan $\mathrm{Pb}-\mathrm{Bi}$ pada LMFBR dilakukan menggunakan kode komputasi DTRIDI-FBR. DTRIDI-FBR merupakan kode komputasi berbasis pemprograman Delphi 7. Perhitungan dilakukan terhadap teras dengan geometri berbentuk kubus ukuran medium $(50 \mathrm{x}$ $50 \times 50) \mathrm{cm}$ dan bahan bakar yang digunakan adalah UN-PuN.

Perhitungan dimulai dari perhitungan neutronik untuk mendapatkan nilai faktor multiplikasi efektif, distribusi fluks neutron dan distribusi rapat daya yang diperoleh dari persamaan difusi multigrup. Persamaan difusi multigrup dapat dilihat pada Persamaan 1 .

$$
\frac{1}{V_{g}} \frac{\partial \phi_{g}}{\partial t}=\bar{\nabla} \cdot D_{g} \bar{\nabla} \phi_{g}-\Sigma_{a g} \phi_{g}+S_{g}-\Sigma_{s g} \phi_{g}+\sum_{g^{\prime}=1}^{G} \Sigma_{s g^{\prime}} \phi_{g^{\prime}}
$$

Hasil perhitungan neutronik diperlukan dalam perhitungan termalhidrolik. Parameterparameter yang dibahas dari hasil perhitungan termalhidrolik berupa distribusi temperatur di setiap bagian teras dan penurunan tekanan di teras. Untuk mendapatkan tingkat sirkulasi alamiah diperoleh dari grafik perpotongan antara pressure drop dan driving head.

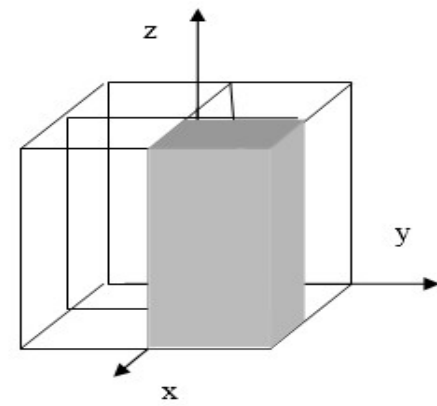

(a) Geometri teras

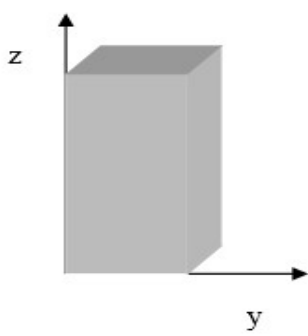

(b) $1 / 4$ bagian teras

Gambar 1 Geometri teras reaktor tiga dimensi 
Model reaktor cepat yang digunakan dalam perhitungan teras untuk mengetahui ketercapaian tingkat sirkulasi alamiah pada empat jenis pendingin logam cair adalah model reaktor daya berukuran kecil dengan spesifikasi desain reaktor seperti yang diperlihatkan pada Tabel 1. Pada model teras dilakukan diskritisasi ruang untuk memperoleh pendekatan dan penyesuaian terhadap model teoritik, seperti terlihat pada Gambar 1. Gambar 1.a memperlihatkan geometri teras tiga dimensi xyz yang digunakan dan Gambar 1.b adalah 1/4 bagian teras. Teras dibagi menjadi beberapa daerah (region) dan tiap region dibagi dalam beberapa mesh.

Tabel 1 Spesifikasi desain reaktor

\begin{tabular}{ll}
\hline Parameter & Spesifikasi \\
\hline Daya reaktor & $150 \mathrm{MWth}$ \\
Variasi pendingin & $\mathrm{Na}, \mathrm{NaK}, \mathrm{Pb}, \mathrm{Pb}-\mathrm{Bi}$ \\
Bahan shielding & $\mathrm{B}_{4} \mathrm{C}+\mathrm{Stainless}$ steel \\
Bahan bakar & $\mathrm{UN}-\mathrm{PuN}$ \\
Pengayaan bahan bakar & $10 \%-20 \%(\mathrm{PuN})$ \\
Reactivity swing & Maksimal 0,002 \\
Diameter pin bahan bakar & $1,0 \mathrm{~cm}$ \\
Tebal cladding & $0,05 \mathrm{~cm}$ \\
Pin pitch bahan bakar & $1,2 \mathrm{~cm}$ \\
Temperatur masukan rata-rata & $330^{\circ} \mathrm{C}$ \\
Temperatur keluaran rata-rata & $500^{\circ} \mathrm{C}$ \\
\hline
\end{tabular}

\section{HASIL DAN DISKUSI}

\subsection{Parameter-parameter neutronik}

Nilai faktor multiplikasi $\left(k_{\text {eff }}\right)$ diperoleh dari rangkaian perhitungan neutronik dan semua desain yang diteliti dengan empat jenis pendingin yang berbeda dapat menunjukkan kondisi kekritisan teras reaktor. Reaktor dalam keadaan kritis $\left(k_{\text {eff }} \sim 1\right)$ dapat dicapai dengan melakukan pengaturan pada pengayaan (enrichment) bahan bakar di teras. Hasil pengaturan pengayaan bahan bakar pada masing-masing bahan pendingin yang digunakan dan nilai $k_{\text {eff }}$ yang diperoleh ditunjukkan pada Tabel 2.

Tabel 2 Fraksi pengayaan dan faktor multiplikasi efektif

\begin{tabular}{ccccccc}
\hline Bahan & \multicolumn{5}{c}{ Fraksi Pengayaan Bahan Bakar (PuN) (\%) } & \multirow{2}{*}{$\boldsymbol{k}_{\text {eff }}$} \\
\cline { 2 - 6 } Pendingin & C1 & C2 & C3 & C4 & C5 & \\
\hline $\mathrm{Pb}$ & 19,5 & 19,5 & 19,0 & 19,0 & 19,0 & 1,000009 \\
$\mathrm{PbBi}$ & 19,5 & 19,5 & 19,1 & 14,0 & 17,0 & 1,000180 \\
$\mathrm{Na}$ & 16,9 & 16,9 & 16,8 & 17,0 & 16,9 & 0,999907 \\
$\mathrm{NaK}$ & 15,3 & 15,25 & 15,0 & 15,0 & 15,0 & 1,000748 \\
\hline
\end{tabular}

Nilai $k_{\text {eff }}$ yang menunjukkan kondisi teras dalam keadaan kritis diperoleh pada fraksi pengayaan yang berkisar antara 15,0\% hingga 19,5\%. Fraksi pengayaan terbesar diperlukan pada desain teras dengan pendingin $\mathrm{Pb}$, hal ini disebabkan karena efek moderasi neutron oleh pendingin $\mathrm{Pb}$ cukup rendah, dengan demikian neutron tetap dalam keadaan energi tinggi (Khalid , 2002).

Selain nilai $\mathrm{k}_{\text {eff, }}$ kondisi neutronik yang baik juga ditunjukkan oleh distribusi fluks neutron dan distribusi densitas daya. Fluks neutron adalah banyaknya neutron yang melewati suatu daerah tiap satuan waktu. Gambar 2 memperlihatkan distribusi fluks neutron arah Y untuk empat grup energi neutron, dimana pola distribusi fluks neutron arah $\mathrm{X}$ simetris dengan arah $\mathrm{Y}$. Pola distribusi fluks neutron ini mengikuti pola cosinus yang sesuai dengan pola distribusi dari referensi seperti pada gambar 4.4 (Waltar dan Reynolds, 1981). 


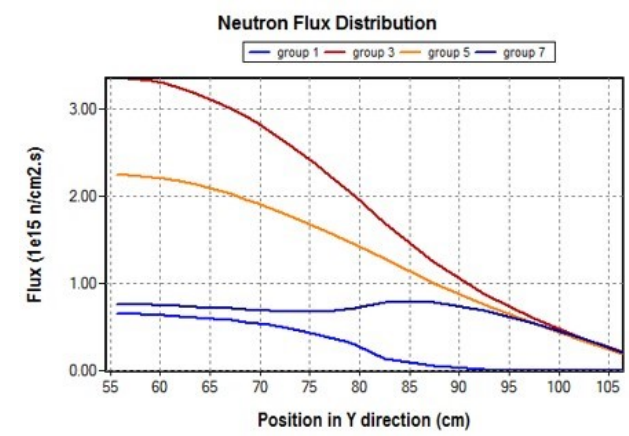

(a) $\mathrm{Pb}-\mathrm{Bi}$

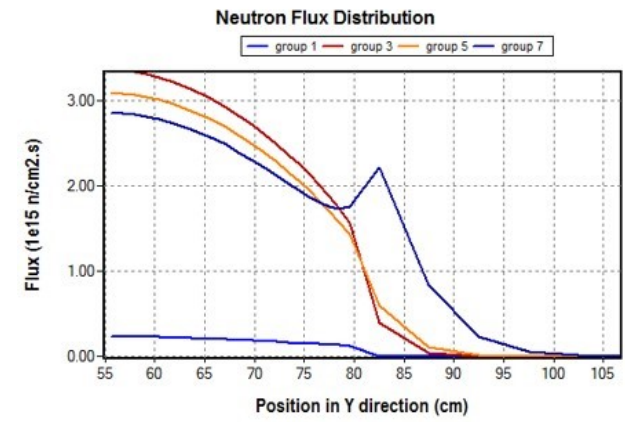

(a) $\mathrm{Na}$

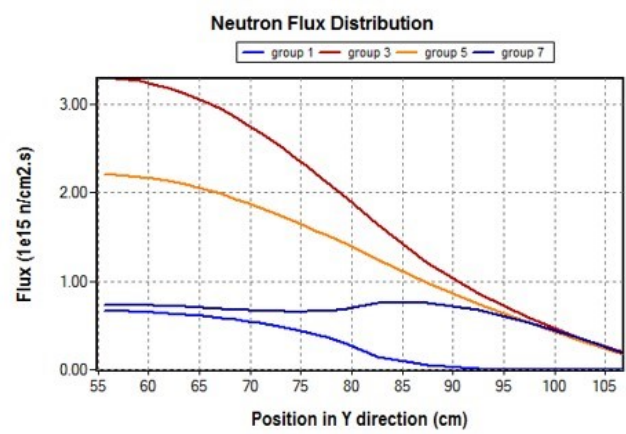

(b) $\mathrm{Pb}$

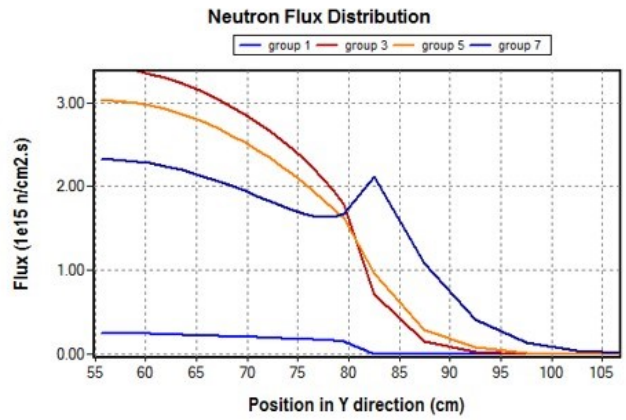

(b) $\mathrm{NaK}$

Gambar 2 Distribusi fluks neutron arah Y

Pola distribusi rapat daya di pusat teras arah Y diperlihatkan pada Gambar 3 pada reflektor harga rapat daya sama dengan nol karena pada daerah tersebut tidak terjadi reaksi fisi, sedangkan fluks pada daerah reflektor merupakan fungsi yang kontinyu karena masih terdapat sejumlah kecil neutron dari bocoran dan absorbsi.

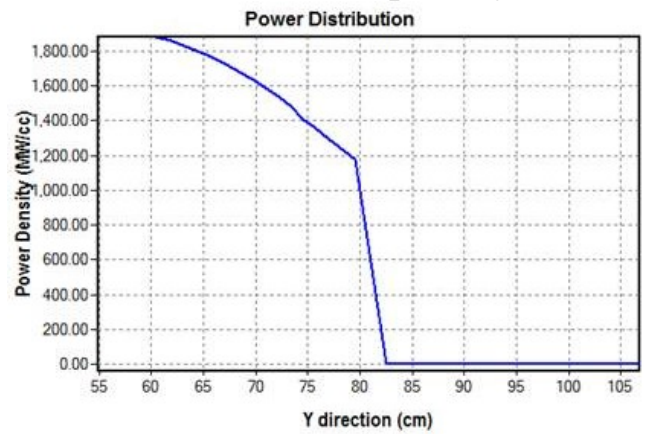

(a) $\mathrm{Pb}-\mathrm{Bi}$

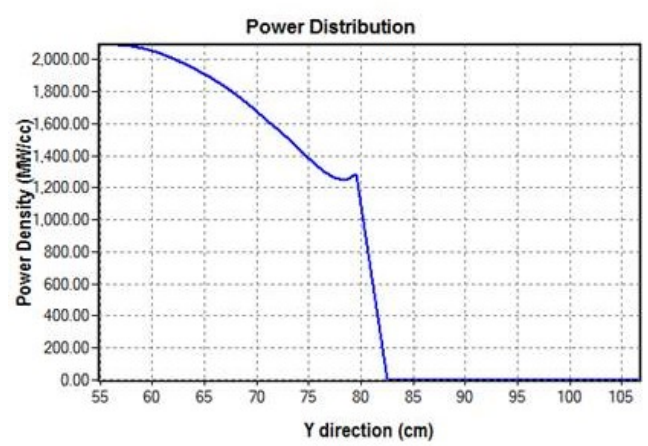

(c) $\mathrm{Na}$

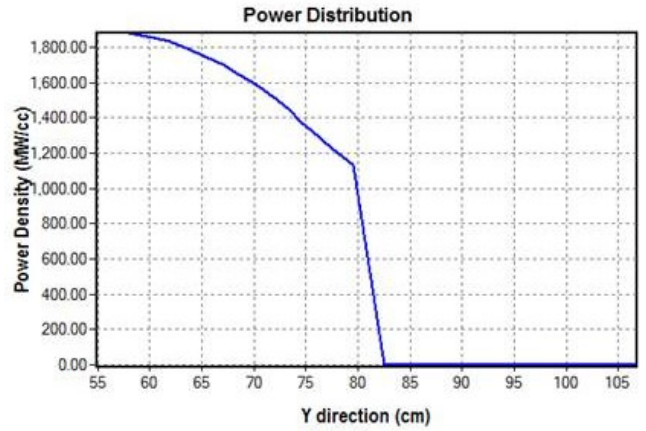

(b) $\mathrm{Pb}$

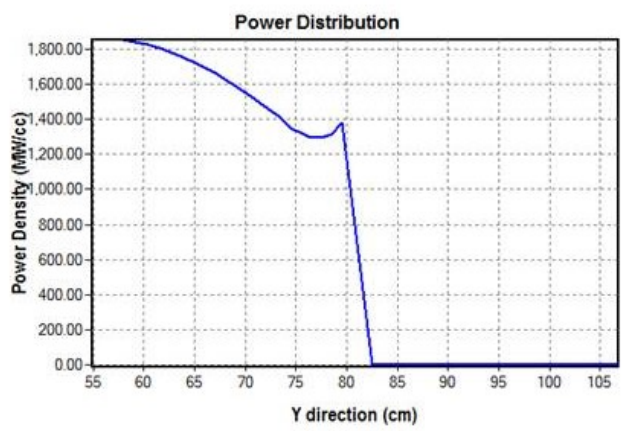

(d) $\mathrm{NaK}$

Gambar 3 Distribusi rapat daya arah Y 


\subsection{Hasil Perhitungan Termalhidrolik}

\subsubsection{Distribusi Temperatur di Teras}

Perhitungan termalhidrolik dilakukan pada laju alir pendingin total mula-mula 4000 $\mathrm{kg} / \mathrm{s}$ untuk masing-masing bahan pendingin dan daya reaktor $150 \mathrm{MWth}$, tetapi untuk Na dan $\mathrm{NaK}$ secara teori diketahui bahwa reaktor cepat dengan pendingin $\mathrm{Na}$ dan $\mathrm{NaK}$ menunjukkan kinerja yang baik dengan laju alir pendingin yang rendah. Pemberian laju alir yang rendah ini disebabkan oleh sifat termo-fisik pendingin tersebut. $\mathrm{Na}$ dan $\mathrm{NaK}$ memiliki koefisien transfer panas yang sangat tinggi, sehingga sangat baik dalam memindahkan panas (Haryani, 2013). Oleh karena itu, pada perhitungan termalhidrolik untuk pendingin $\mathrm{Na}$ dan $\mathrm{NaK}$ menggunakan laju alir pendingin total $1000 \mathrm{~kg} / \mathrm{s}$ sehingga mampu menunjukkan performa yang baik.

Gambar 4 menunjukkan distribusi temperatur pendingin, temperatur cladding dan temperatur bahan bakar disepanjang arah z. Secara umum temperatur mengalami peningkatan di bagian tengah teras reaktor dan turun di bagian tepi, hal ini disebabkan karena distribusi densitas daya yang cukup tinggi di bagian tengah teras. Nilai temperatur tertinggi terjadi pada bahan bakar di bagian pusat (centre).

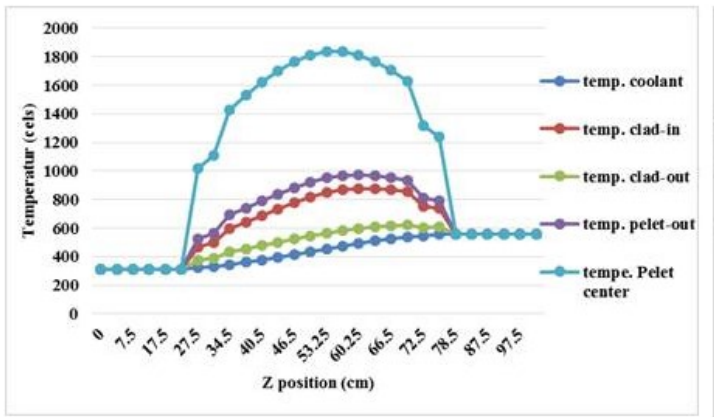

(a) $\mathrm{Pb}-\mathrm{Bi}$

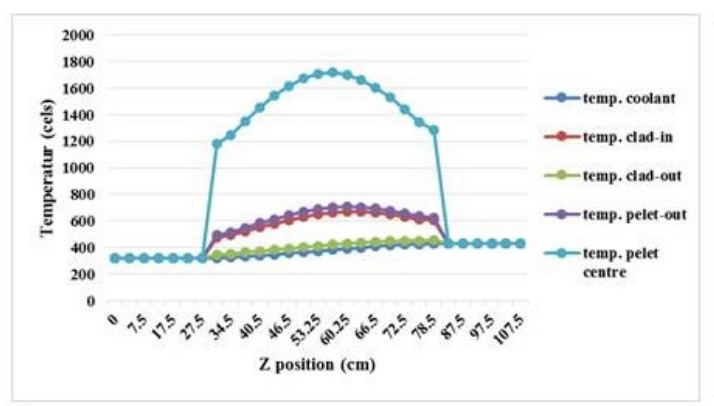

(c) $\mathrm{Na}$

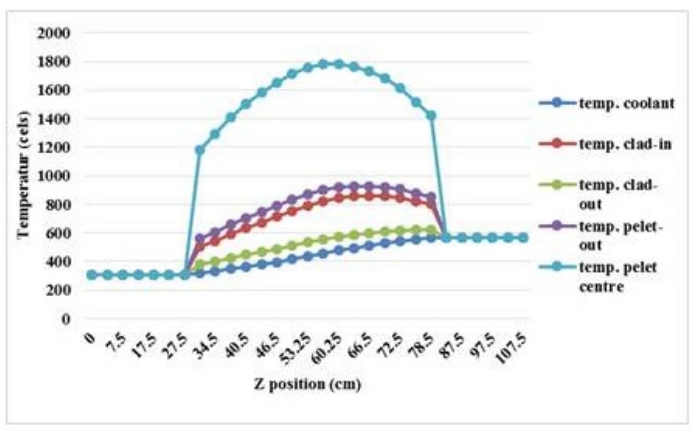

(b) $\mathrm{Pb}$

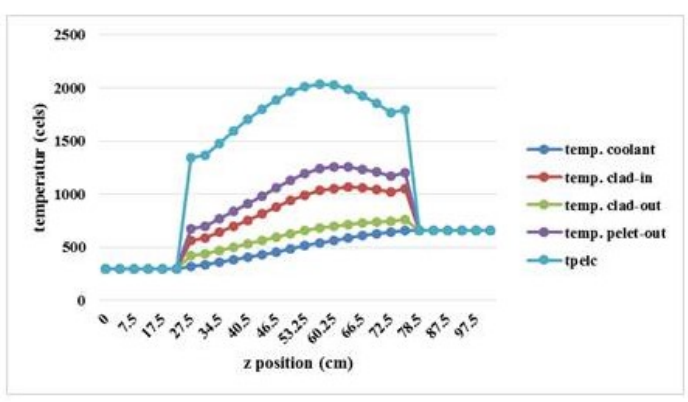

(d) $\mathrm{NaK}$

Gambar 4 Distribusi temperatur di setiap bagian teras

\subsubsection{Penurunan Tekanan}

Penurunan tekanan (pressure drop) merupakan besaran yang menunjukkan perbedaan tekanan pada kanal pendingin sebelum dan sesudah pendingin melewatinya. Nilai penurunan tekanan yang diperoleh dari hasil perhitungan untuk semua jenis pendingin ditunjukkan pada Tabel 3.

Tabel 3 Tekanan pada setiap penggunaan bahan pendingin

\begin{tabular}{ccccc}
\hline $\begin{array}{c}\text { Jenis } \\
\text { Pendingin }\end{array}$ & $\begin{array}{c}\text { Laju Alir } \\
\text { Total (Kg/s) }\end{array}$ & $\begin{array}{c}\text { Pressure Drop } \\
\text { (MPa) }\end{array}$ & $\begin{array}{c}\text { Driving Head } \\
(\mathbf{M P a})\end{array}$ & $\begin{array}{c}\text { Daya Pompa } \\
\text { (MPa) }\end{array}$ \\
\hline $\mathrm{Pb}$ & 4000 & 1,502 & 0,213 & 1,289 \\
$\mathrm{~Pb}-\mathrm{Bi}$ & 4000 & 1,108 & 0,096 & 1,012 \\
$\mathrm{Na}$ & 1000 & 0,769 & 0,080 & 0,689 \\
$\mathrm{NaK}$ & 1000 & 0,986 & 0,095 & 0,891 \\
\hline
\end{tabular}


Perbedaan antara pressure drop dan driving head memberikan perkiraan besarnya daya pompa. Laju alir total pendingin yang lebih besar seperti pada $\mathrm{Pb}$ dan $\mathrm{Pb}-\mathrm{Bi}$ akan membuat penurunan tekanan yang melintasi teras akan semakin tinggi, sehingga daya pompa yang diperlukan juga semakin besar. Laju alir yang lebih kecil pada penggunaan $\mathrm{Na}$ da $\mathrm{NaK}$ memberikan pressure drop yang lebih kecil sehingga daya pompa yang diperlukan juga semakin kecil. Reaktor dengan daya pompa yang lebih kecil dari aspek keselamatan akan lebih aman ketika terjadi kondisi kecelakaan ULOF.

\subsection{Sirkulasi Alamiah}

Pada kondisi kecelakaan ULOF laju aliran pendingin menurun akibat hilangnya daya pompa, oleh karena itu simulasi kecelakaan diawali dengan menurunkan harga laju alir total secara bertahap. Sirkulasi alamiah mengacu pada kemampuan bahan pendingin untuk bersirkulasi secara terus menerus. Tingkat sirkulasi alamiah bahan pendingin didapatkan dari grafik perpotongan antara penurunan tekanan di teras dan driving head sebagai fungsi dari laju alir total, dapat dilihat pada Gambar 5.

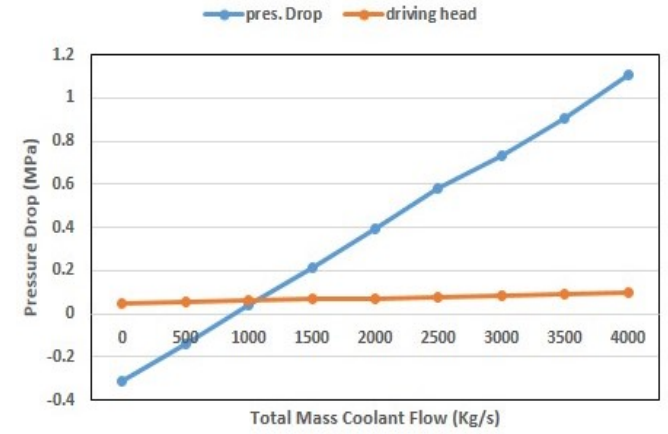

(a) $\mathrm{Pb}-\mathrm{Bi}$

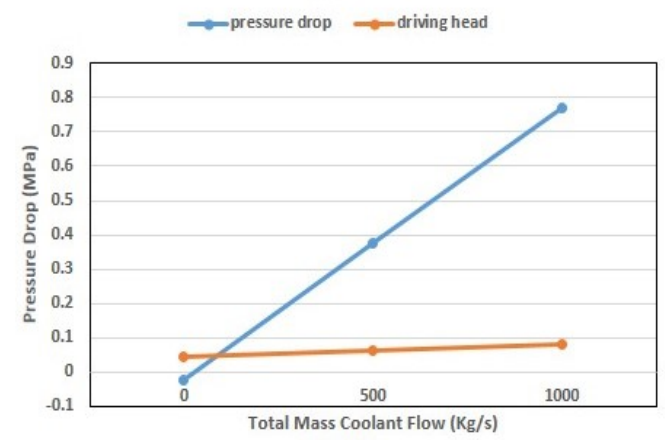

(a) $\mathrm{Na}$

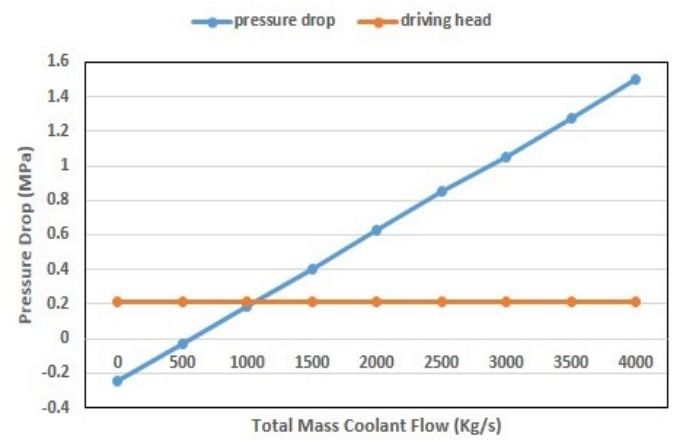

(b) $\mathrm{Pb}$

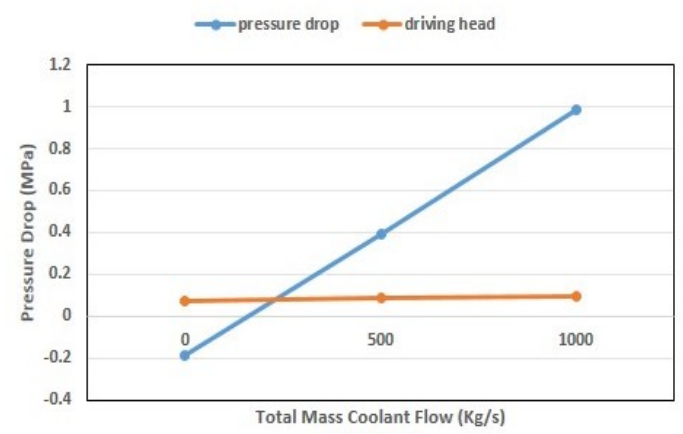

(b) $\mathrm{NaK}$

Gambar 5 Perubahan penurunan tekanan dan driving head

Tabel 4 memperlihatkan bahwa tingkat sirkulasi alamiah pada $\mathrm{Pb}$ dan $\mathrm{Pb}-\mathrm{Bi}$ dapat dicapai pada laju alir $\sim 1100 \mathrm{~kg} / \mathrm{s}$ atau $27,5 \%$ relatif terhadap laju alir total semula yaitu 4000 $\mathrm{kg} / \mathrm{s}$. Saat terjadi sirkulasi alamiah dengan pendingin $\mathrm{Pb}$ temperatur pelet maksimum yang dihasilkan sekitar $2103,946^{\circ} \mathrm{C}$. Harga ini masih berada di bawah titik leleh bahan bakar UN$\mathrm{PuN}$ yaitu sekitar $2500^{\circ} \mathrm{C}$. Pada penggunaan bahan pendingin $\mathrm{Pb}-\mathrm{Bi}$ saat terjadi sirkulasi alamiah temperatur pelet maksimum sebesar $2138,794^{\circ} \mathrm{C}$. Artinya jika terjadi kecelakaan ULOF reaktor berada dalam keadaaan aman.

Tabel 4 Tingkat sirkulasi alamiah

\begin{tabular}{cc}
\hline Pendingin & Tingkat sirkulasi alamiah (\%) \\
\hline $\mathrm{Pb}$ & $\sim 27,5$ \\
$\mathrm{~Pb}-\mathrm{Bi}$ & $\sim 27,5$ \\
$\mathrm{Na}$ & $\sim 10,0$ \\
$\mathrm{NaK}$ & $\sim 20,0$ \\
\hline
\end{tabular}


Pada penggunaan pendingin $\mathrm{Na}$ dan $\mathrm{NaK}$ tingkat sirkulasi alamiah sangat kecil, yaitu pada laju alir $\sim 100 \mathrm{~kg} / \mathrm{s}$ dan $\sim 200 \mathrm{~kg} / \mathrm{s}$. Temperatur pelet maksimum saat terjadi sirkulasi alamiah pada penggunaan pendingin $\mathrm{Na}$ adalah $1870,644^{\circ} \mathrm{C}$ dan $\mathrm{NaK}$ sebesar $2331,038^{\circ} \mathrm{C}$. Harga ini masih berada dibawah titik leleh bahan bakar yang digunakan.

\section{KESIMPULAN}

Analisis tingkat sirkulasi alamiah pada LMFBR dengan pendingin $\mathrm{Na}, \mathrm{NaK}, \mathrm{Pb}$ dan $\mathrm{Pb}-\mathrm{Bi}$ telah berhasil dilakukan dengan hasil tingkat sirkulasi alamiah lebih mudah dicapai pada penggunaan bahan pendingin $\mathrm{Pb}$ dan $\mathrm{Pb}-\mathrm{Bi}$, yaitu sekitar 27,5\% dari laju alir total semula 4000 $\mathrm{kg} / \mathrm{s}$, yang berarti reaktor lebih mampu bertahan terhadap kondisi kecelakaan ULOF, dan kondisi ini berarti akan semakin baik tingkat keselamatan dari reaktor.

\section{DAFTAR PUSTAKA}

Haryani, N dan Fitriyani, D., "Pengaruh Variasi Bahan Pendingin Jenis Logam Cair Terhadap Kinerja Termalhidrolik Pada Reaktor Cepat", "Jurnal Fisika Unand, Padang, 190-194, 2013

Khalid R,A dan Aziz,F., "Analisis Void pada Reaktor cepat kecil berpendingin TimbalBismuth", Prosiding Seminar ke-7 Teknologi dan Keselamatan PLTN serta Fasilitas Nuklir, Jurusan Fisika ITB, Bandung, 98-112, 2002.

Novitrian dan H.Sofue., Study on Pb-Bi natural Circulation Phenomena, INES-1, Tokyo-japan, 2004.

Oktamuliani, S dan Fitriyani, D., 2011, “Analisis Pengaruh Ukuran Teras Terhadap Tingkat Sirkulasi Alamiah Bahan Pendingin Pb-Bi Pada Reaktor Cepat”, (Jurnal Fisika Unand, Padang, 53-61, 2011

Reynolds, W.C. dan Henry, C.P., Termodinamika Teknik Erlangga, Jakarta, 1996. 